\title{
The impact of immigrants' segregation and concentration on social integration in selected European contexts
}

\author{
Sako Musterd \\ University of Amsterdam. Department of Geography, Planning and International \\ Development Studies \\ S.Musterd@uva.nl
}

\begin{abstract}
In large sections of the western world there are lively public and policy debates about segregation and integration and in particular about the potential impact of specific population compositions in certain neighbourhoods in cities on integration and social opportunities. There clearly are some prevailing ideologies, perceptions, assumptions and policy responses regarding segregation and potential (neighbourhood) integration effects. In this contribution these prevailing ideas will be addressed and subsequently confronted with theory on segregation, concentration, and neighbourhood effects, and finally confronted with empirical research and evidence.

What we learned is that segregation and concentration are no straightforward concepts and thus require cautious treatment. This may help to reduce xenophobic reactions. There are indications, though, that even in so-called redistributing welfare states some (negative) impacts of immigrant concentrations on individual's prospects can be discerned. However, here too, careful analyses are required to be able to clarify when, for whom, what effects will likely have to be expected.
\end{abstract}

Key words: international migration; immigrants; segregation; concentration; social integration.

Resum. L'impacte de la segregació i la concentració dels immigrants sobre la seva integració en alguns contextos europeus

En el món occidental, l'impacte de certes composicions de la població en determinats barris d'algunes ciutats, com també la segregació i la integració dels immigrants i les oportunitats socials d'aquests, és motiu de debat públic i polític. Aquest article analitza les ideologies, les percepcions, les suposicions i les respostes polítiques predominants, referides als efectes potencials de la segregació i de la integració en els barris, per confrontar-les després amb les teories de segregació, concentració i efectes de barri (neighbourhood effect), així com amb altres recerques empíriques.

Els resultats ens mostren que els termes segregació i concentració són conceptes complexos i que, per tant, han d'ésser tractats amb precaució. Així possiblement es reduirien les reaccions xenòfobes. De totes maneres, existeixen indicis que, fins i tot en estats del benestar redistributius, la concentració d'immigrants té alguns efectes (negatius) sobre les 
expectatives dels individus. Malgrat tot, fan falta anàlisis molt específiques per aclarir quan i qui serà afectat per aquesta qüestió i quins en seran els efectes més probables que provocarà. Paraules clau: migració internacional; immigrants; segregació; concentració; integració social.

Resumen. El impacto de la segregación y la concentración de los inmigrantes sobre su integración en algunos contextos europeos

El impacto de ciertas composiciones de la población en determinados barrios de algunas ciudades, asi como la segregación e integración de los inmigrantes y las oportunidades sociales de éstos, es motivo de debate público y político en el mundo occidental. El presente artículo analiza las ideologías, las percepciones, las suposiciones y las respuestas políticas predominantes referidas a los efectos potenciales de segregación e integración de los barrios, para confrontarlas después con las teorías sobre segregación, concentración y efectos de barrio (neighbourhood effect), así como con los indicios existentes a partir de otras investigaciones.

Los resultados nos muestran que los términos segregación y concentración son conceptos complejos y, por lo tanto, deben ser tratados con cautela. Así posiblemente se reducirían las reacciones xenófobas. De todas formas, existen indicios de que, incluso en estados del bienestar redistributivos, la concentración de inmigrantes tiene algunos efectos (negativos) sobre las expectativas de los individuos. Sin embargo, se requieren análisis muy específicos para clarificar cuándo y quién será afectado por dicha cuestión y cuáles serán los efectos más probables que provocará.

Palabras clave: migración internacional; inmigrantes; segregación; concentración; integración social.

Résumé. Impact de la ségrégation et de la concentration des immigrants sur leur intégration dans des contextes européens particuliers

Dans de nombreux endroits du monde occidental, la question de la ségrégation et de l'intégration anime de nombreux débats publics et politiques, et traitent plus spécifiquement de l'impact potentiel de certaines composantes de la population dans les quartiers, de la capacité d'intégration et des opportunités sociales qui se présentent. Il existe clairement des idéologies, des hypothèses et des réponses politiques dominantes qui encadrent la ségrégation et ses conséquences éventuelles sur l'intégration. Cet article questionne ces idées dominantes en les confrontant dans un premier temps aux théories de la ségrégation, de la concentration, et des effets de quartiers (neighbourhood effect), puis finalement à la recherche empirique et à ses résultats.

L'étude nous enseigne que les concepts de ségrégation et de concentration ne sont pas évidents et qu'ils doivent être employés avec prudence. Cela pourrait aider à réduire les réactions xénophobes. Il apparait cependant que, même dans les soi-disant États-providence, la concentration des immigrants ait des conséquences (négatives) sur les perspectives individuelles. Cependant, ici aussi, des analyses minutieuses sont indispensables pour en identifier la portée : quels en sont les effets, à quel moment se font-ils ressentir et sur quelles populations.

Mots clé: migration internationale; immigrants; ségrégation; concentration; intégration sociale. 


\section{Summary}

Introduction, questions and concepts

Key concepts, ideologies and theories

Spatial patterns of concentration and segregation of immigrants in selected European contexts and their dynamics: empirical findings
Relations between patterns of concentration and segregation and indicators of (social) integration Conclusions and implications for policies References

\section{Introduction, questions and concepts}

Cities across the world are experiencing international migration of several kinds: rich and poor; skilled and unskilled, between East and West, North and South; with or without specific religious backgrounds, etc. These ongoing movements of people result in various responses from societies where migrants intend to settle, ranging from trying to keep immigrants out; to selective exclusion based on ethnic belonging; to assimilation models, where the immigrant is welcome but only if there is willingness to adapt to the host society; to the pluralist multicultural model, where migrants are accepted on the basis of the notion that the country is a place for a diverse population (see for example Castles and Miller, 1993; Alexander, 2003). There is much difference between states, and despite increasing globalisation we do not see a strong convergence of immigration and migrant policies. State models still seem to matter. This was recently confirmed by Diane Sainsbury (2006) who compared the immigration policies of three archetypical welfare states, the US, Sweden and Germany. She once more concluded $" \ldots$... different immigration regimes exhibit diverse responses, reflecting in part the strength of dissimilar policy legacies and differing policy logics of exclusion and inclusion» (p. 243).

However, initial preferences for certain policies do not imply that policies are fixed forever. In Western Europe in particular, there are clear signals of change in attitudes towards immigrants' insertion. This is reflected in policy shifts, especially from more inclusive pluralist models towards more exclusionary policies and towards one-sided assimilation types of 'integration'.

In the debates that accompany these shifts and new viewpoints, an essential role is given to the geographical dimension. It is not just about the fear for the development of parallel societies in general, or the wish to assimilate the newcomers as soon as possible, but it is about a specific fear for the development of 'spaces apart', and it is about the idea that spatially segregated or concentrated population categories hinder assimilation or integration processes. Geography appears to have taken centre stage. This is also illustrated with the more frequent application of concepts such as immigrant —or sometimes ethnicsegregation and concentration, and with the expression of the assumption that higher levels of segregation and concentration relate negatively to the levels of assimilation or integration (see for example recent special issues of the Journal of Housing and the Built Environment on combatting residential 
segregation of ethnic minorities in European cities (for example Bolt, 2009); or of the Journal of Ethnic and Migration Studies on linking integration and residential segregation (for example Bolt et al., 2010; Arbaci and Malheiros, 2010). However, the logics and assumptions related to the association between uneven spatial distributions, perceived changes in them, and levels of integration are not shared by all and thus open for debate. There is, in fact, even little knowledge about the levels and dynamics of spatial inequality. Therefore, the following leading questions are formulated for this paper:

- What are the prevailing patterns of segregation and concentration of immigrants in selected European contexts and how dynamic are these patterns?

- To what extent are the patterns of segregation and concentration related to indicators of (social) integration?

- What does that imply for policies aimed at enhancing the integration of immigrants in society?

This paper starts (in section 2) with an elaboration of the key concepts used in this paper, and a sketch of the ideologies and theories on the relation between patterns of concentration and segregation and (social) integration. This will be followed by some empirical sections, starting with section 3 on the spatial patterns of concentration and segregation of immigrants in selected European contexts and on their dynamics. Section 4 will elaborate on the relations between immigrant's concentration and segregation and indicators of (social) integration. In section 5, finally, conclusions will be drawn and some policy implications will be discussed.

\section{Key concepts, ideologies and theories}

The key concepts in the debate are 'segregation', 'concentration', 'integration', and 'immigrants'. In geography, segregation is frequently defined through the so-called dissimilarity index $\mathrm{D}$, which expresses the level of spatial inequality between population categories in an (urban) system (Duncan and Duncan, 1955; Massey and Denton, 1988). The D says something about the level of unevenness of spatial distributions and is relevant to obtain answers to questions such as: is there a tendency for two population categories to become more or less spatially divided?; is there a tendency of a population category to strengthen their own population category's spatial distribution? Another measure of segregation, which is frequently applied, is the index of isolation, $\mathrm{P}^{*}$. This index expresses the probability of meeting someone of one's own category in one's own neighbourhood, and is also expressed for the system as a whole. The $\mathrm{D}$ and $\mathrm{P}^{*}$ are measuring different things and thus not necessarily show similar tendencies. In the city of Rotterdam, The Netherlands, for example, between 1994 and 2009, the D-value for Moroccans dropped with more than ten per cent, from 56 to 50 , while the $\mathrm{P}^{*}$ increased with over 35 per cent, from 8.1 to 11.0. It is, therefore, important to carefully decide which measure 
of segregation is chosen. The concept of integration is perhaps just as difficult to apply, because a range of indicators can be used for measuring it. I refer to social integration and focus on the level of social participation, which may be indicated by the level of participation in the economy (income level), in the labour market (level of unemployment), or in education (level of education). Here the focus will be on income.

Because of the difficulty with the general indexes used to measure segregation and integration for entire urban systems, alternative approaches have been developed in which the relative concentration of a category in an area is taken as a point of departure (see Philpott, 1978; Peach, 1996; Musterd and Ostendorf, 2009). A relative concentration is defined as an overrepresentation of a population category in an area. The idea is to start with the concentrations, investigate, for example, the average share of a population category in these areas, but also other things, such as the share of a population category living in concentration areas relative to all members of the population category in the system as a whole. In addition, the dynamics with regard to these representations in concentrations can be investigated. The aim is to better focus on the extent to which members of a population category live apart from others and how that is changing over time using as much of the information as possible and approaching segregation as a process (also see Johnston, Poulsen and Forrest, 2008; Deurloo and De Vos, 2008). Living in relative concentrations can also be used to investigate the individual level association between the level of social participation and the level of concentration, controlling for a range of other impacts on social participation.

Immigrants are not defined similarly everywhere. In some contexts there is reference to first generation immigrants; in others also second generation nonnatives are included; some refer to nationality, others to non-nativity; some analyze per origin, others apply categories, such as non-Western or Western.

In the literature we find different ideologies with regard to the relation between immigrant concentrations and levels of social integration; these tend to associate with different attitudes towards immigrant's insertion in the wider society. One view sees immigrants as newcomers or as outsiders who may or may not become established later on (Elias and Scotson, 1994). They will be differently approached depending on their and the settled residents' views on whether they will be there only temporarily or more permanently. Another view is one that stresses the differences in terms of cultures or subcultures, which may go hand in hand with very different responses. One of the responses is to develop a ban on immigration in order to prevent the change of 'one's own' culture. The second response is opposite to the first and adopts a pluralist view: difference is not expected to disappear, but is celebrated and regarded an enrichment for the multicultural society (also Peach, 1997).

Different views translate in different policy attitudes, which are articulated in various policy domains. These relate to access to society and the legal and civic status; to labour market access, education, access to social services, openness towards a variety of cultural and religious institutions, and also to housing. 
The views and ideologies have their parallel expressions in space. Frederick Boal (1976) used the concept of 'colony' to refer to a temporary immigrant community or concentration that would eventually disappear either because of assimilation or because their inhabitants again would leave the country. Boal used the concepts of an 'enclave' to refer to a more permanent voluntary segregated ethnic community. Van Amersfoort's (1992) used the concept of 'ethnic neighbourhood' and 'ethnic concentration' to refer to more permanent and significantly segregated communities, and the concept of 'ghetto' for the institutionalised form of segregation. These ethnic concentrations can again be approached as something that is accepted or welcomed and fitting post-modern pluralist or multicultural views of society, but may also be seen as a proof that 'integration' - in the meaning of assimilation - has failed. Those who adopt the latter view often use the concept of 'segregation' as a metaphor of 'a bad thing'.

These ideologies go hand in hand with opinions about the development of segregation and the effects of it. For example, those who fear segregation also tend to believe that segregation levels are high and increasing; those who do not fear segregation and unequal spatial patterns do not talk about high and increasing levels. Those who blame immigration for a range of failures in society also say that segregation and integration are negatively related to each other and that segregation causes negative effects (Massey and Denton 1993). Where the fear for parallel societies and other xenophobic reactions are strongest, the call for assimilation and dispersal, or even deportation, is loudest. It is striking to see that lack of integration is frequently associated with spatial — neighbourhoodcharacteristics and with the idea that there are negative 'neighbourhood effects' related to segregation. This often results in a call for neighbourhood restructuring and neighbourhood mix (in ethnic or social terms).

Segregation and concentration processes and their relations with integration have to be understood before decisions are made about interventions and targeted policies in these spheres. This paper aims to contribute to that understanding, while presenting empirical findings from various sources in the following sections. In this section reference will be made to existing theories and a selection of established empirical knowledge of segregation, concentration and the potential impacts on integration.

\section{«Causes»}

There is a range of theories related to the development of spatial inequality (Burgers and Musterd, 2002). First, there is a body of literature on the impacts of globalization and economic restructuring processes on the levels of inequality and polarization; inequalities are reflected in segregation within cities (Sassen, 1991). Differentiation in purchasing power in capitalist societies will produce spatial segregation. Similar processes may have an impact on mismatches in the labour market (Wilson, 1987) and this will result in higher levels of segregation as well. Secondly, there is a literature referring to the relation between type of welfare regimes and levels of segregation (Musterd and 
Ostendorf, 1998; Sainsbury, 2005). Segregation levels tend to be high for socalled residual welfare states; they are lower in extensive welfare regimes; and are lowest in universal welfare states (Domburg-De Rooij and Musterd, 2002). There are associations between levels of segregation and the income redistribution schemes of welfare states. Segregation will be more moderate where redistribution is more developed; a similar relation exists with the availability of benefit systems for the unemployed, elderly and disabled; access to high quality education; access to good housing and to the labour market; the functioning of the housing market and housing benefit systems; and health care systems access. They tend to be better developed in uniform welfare regimes and have segregation reducing effects. Thirdly, segregation levels are influenced by cultural factors. It is important to know whether there is much difference in terms of the language spoken, the religions that are present, and what the levels of discrimination are, etceteras. Fourthly historical social, economic and cultural urban pathways are relevant. Segregation may have developed centuries ago and this may still have an impact upon the contemporary patterns. Finally, there may be political factors: attitudes towards diversity, the level of acceptance of inequality, tolerance towards difference, eagerness to 'enforce' integration, and ideas regarding assimilation; multiculturalism and mix.

What comes out of a review of segregation and concentration is that these processes are strong and influenced by the level of and differences in the social, economic, and cultural capital that is available. Moreover, concentration and segregation are influenced by global, national, local and group level processes, by structural and individual factors.

\section{«Effects»}

If we focus on the immigrant related neighbourhood or segregation effect literature, a range of theories may be referred to. The first relates to socialisation processes and role models. There is a belief that segregated immigrants will become insufficiently socialized in their new environment and because of lack of good role models may become disconnected from mainstream society. A second field of theory connects to the role of social networks. Individuals might get access to a range of services and (economic) activities through social networks. When the segregated situation prevents the development of these wider networks, individuals would become cut off from a range of opportunities. If personal contacts are limited to members of a class-homogeneous group of immigrants from the same country of origin, only limited 'bridging' social capital will be built up and social isolation can result (Waldinger, 1997). Thirdly, some areas may become stigmatized on the basis of their specific characteristics (Wacquant, 1993). This will happen more easily in segregated neighbourhoods than elsewhere. A fourth field of theory on impact of environment yields contradictory results. That field is related to ethnic clustering in relation to ethnic businesses and entrepreneurships. Some have argued that groupings of specific ethnic businesses create benefits to immigrant employees from that ethnic group 
(Portes, 1995; Kloosterman and Rath, 2003). Ethnic businesses may provide more effective informal on-the-job training and apprenticeships (Portes and Zhou, 1992). Borjas (1998) refers to the notion of 'ethnic capital', that is the amount of human capital present among earlier generations of immigrants that is expected to improve the chances of economic success of their children because they will receive better intergenerational transmissions of social and human capital, norms for educational attainment, educational and job information, and employment opportunities. However, others argued that excessive reliance by immigrant entrepreneurs on local ethnic networks may hinder efforts to diversify, thereby limiting profits and increasing vulnerability to shocks (Sanders and Nee, 1996). If the ethnic concentration completely serves all social and institutional needs, new immigrants may have less motivation to assimilate and develop host-country language and other skills (Massey and Denton, 1987).

Other, empirical, studies only seem to add to the confusion. Borjas (1995) revealed that the percentage of immigrants in the census tract that was of the same ethnicity as the observed persons when they were youths had a strong positive correlation with their later educational attainment and wages, controlling for age, gender, first-or second-generation immigrant status, and parental skill levels. However, contrary to Borjas (1995), Galster et al. (1999) found that exposure to more members of one's own immigrant group was associated with growing rates of poverty and lower gains in employment, on average for the group, during the subsequent decade. Clark and Drinkwater (2002) found that the percentage of neighbours that were members of the minority individual's same ethnic group in 1991 significantly raised their risk of being unemployed in 1993-94, and reduced their chances of being self-employed. Van der Klaauw and van Ours (2003) found that the percentage of non-Dutch in the neighbourhood was not a statistically significant predictor of exits from welfare for immigrants.

In short, there does not seem to be consistent theoretical nor empirical evidence of the existence of negative or positive effects of the immigrant composition of neighbourhoods on social outcomes of those who reside in these neighbourhoods. This implies that a range of ideologies and policies is based on shaky assumptions about levels and developments of segregation and concentration of immigrants, and on their association with social outcomes of those who reside in ethnic concentrations. Therefore, in sections 3 and 4 I will provide some recent and new empirical evidence on levels and dynamics of segregation and concentration in selected European urban contexts and further investigate their impact on individual's economic performances.

\section{Spatial patterns of concentration and segregation of immigrants in selected European contexts and their dynamics: empirical findings}

Unlike the US, the European Union still has no standard of measuring levels of segregation in metropolitan areas, let alone that standardised areal units and definitions of immigrants are available. Moreover, European cities have their own and very different migration histories, and some categories of migrants 
can be found in some cities, but other categories can be found in others. In some contexts well-organised registers are available, but not in other contexts. Uniformity is therefore hard to find, in all respects. This implies that only patchwork comparisons can be made, based on independent sources per case.

Overall, segregation levels are relatively low in EU cities when compared to US cities (Musterd, 2005; Musterd and Van Kempen, 2009; Arbaci and Malheiros, 2010). Exceptions may be found for UK cities, where we find relatively high scores for Bangladeshi; and in new immigration environments, such as in Barcelona, where Moroccans show high levels of segregation. Timing of immigration, duration of stay, and housing conditions, as well as housing market regulations seem to play a role in the explanation, but for some categories also cultural motives may be important (Peach, 1999). There appear to be more cities with a stable or decreasing level of segregation than situations of segregation increase. In Figure 1 some examples of dynamics (and levels in recent years) have been shown for illustration.

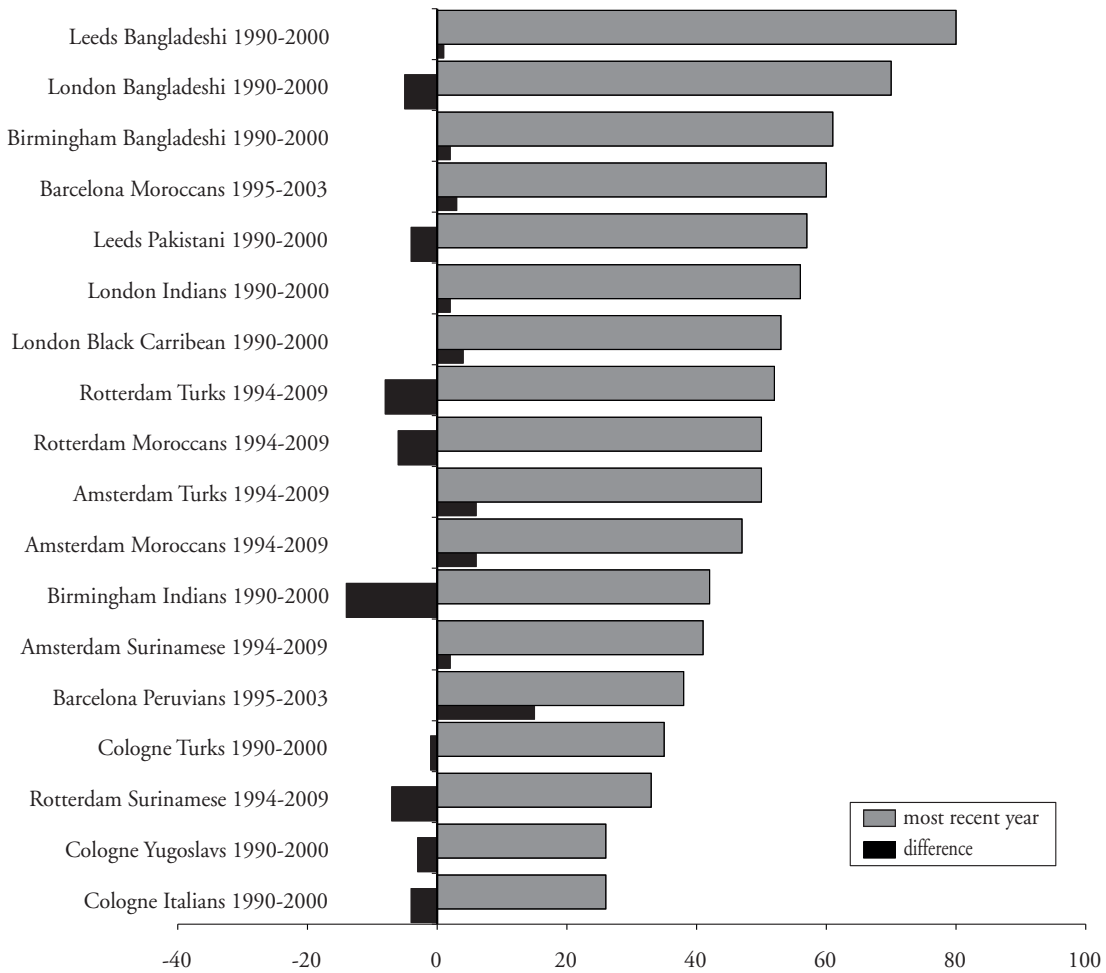

Figure 1. Segregation level (D) and development (difference between years mentioned) for selected cities and selected population categories.

Sources: Arbaci (2007); Friedrichs (1998); Malheiros (2002a, b); Martori et al. (2005); Musterd (f.c.) (1996); Peach (1996); Stillwell \& Phillips (2006). 
When zooming in on Dutch cities, we see that Amsterdam and Rotterdam are showing some contrasting developments, even though they are embedded in the same welfare state. From other research we know that D-values in Amsterdam started at a much lower level compared to those in Rotterdam (see Musterd f.c.), but what is shown here is that directions of development of the level of segregation of Turkish and Moroccan residents are almost opposite. The index of Isolation values, however, is rising in both cities.

Although these time-series overviews provide relevant data to be used in judging changing levels of segregation, separation or integration, we agree with commentators who argue that often more information can be pulled out of existing data sets, especially when these are rich in geographic terms. In this section some recent studies on Amsterdam will be referred to that illustrate this point. New empirical material is presented as well. As a start some general information on the development of the four most important population categories in the Dutch capital is shown in Figure 2. The shares of Amsterdam inhabitants from Surinamese and Moroccan origin are converging to and seem to be stabilising at a level of nine per cent each, while Amsterdam inhabitants from Turkish origin might have reached their maximum around five per cent and Antilleans at 1.5 per cent. Together they make up 25 per cent of the population.

The initial steps of the studies on concentrations refer to GIS based calculation of so-called concentration areas on the basis of detailed spatial data (examples used here refer to six-digit postcode areas) (Figure 3). Concentrations are based on taking together adjacent postcode areas that fulfil certain concentration criteria. When these concentration areas have been formed, these can be used for various subsequent analyses. For example, in a study of the instability

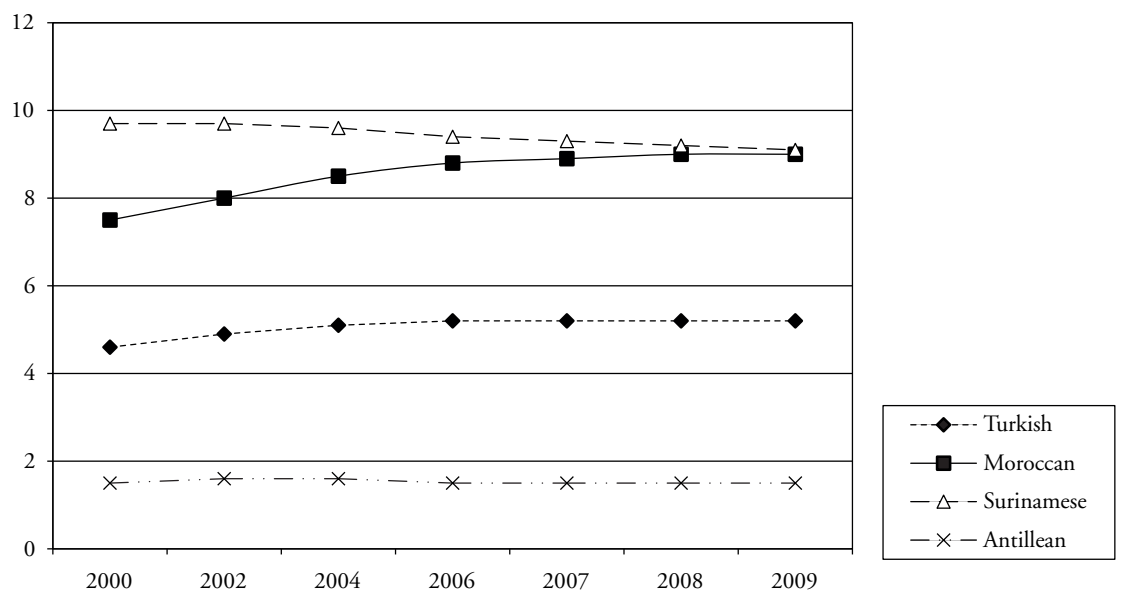

Figure 2. Percentage of four population categories relative to the Total population of Amsterdam, 2000-2009, based on country of origin ( $1^{\text {st }}$ and $2^{\text {nd }}$ generation). 
of these concentrations demographic change due to birth, death and migration of a range of population categories could be measured for individual concentrations and this led to insights that in Amsterdam Turkish concentrations that existed in 1994 tended to become less instead of more Turkish over the period between 1994 and 2004 (Musterd and De Vos 2007).

Here I will present more recent research evidence on these 'ethnic' concentrations using these detailed data for the city of Amsterdam, but arranged in such a way that more can be said about isolation, separation and encapsulation than can be done on the basis of crude measures of segregation (also see Philpott 1978, Peach 2009, Musterd and Ostendorf 2009).

In Table 1 an example is given of the type of information that can be used, here for one year, 2009, for each of the four population categories. In the following Figures 4 and 5 information is shown which is equivalent to those calculated for columns 6, resp. 7 in Table 1 .

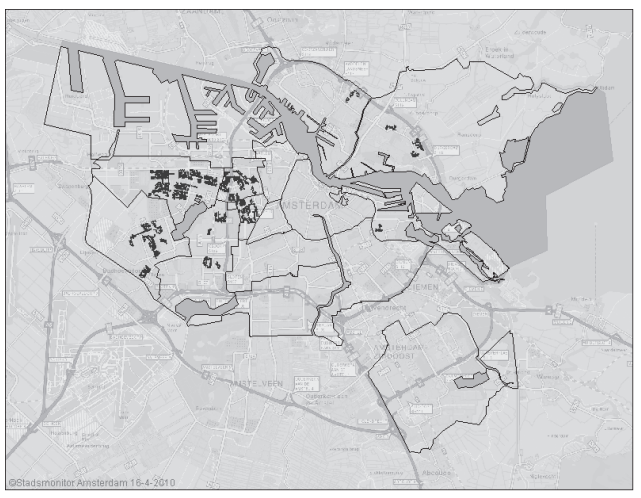

Turkish

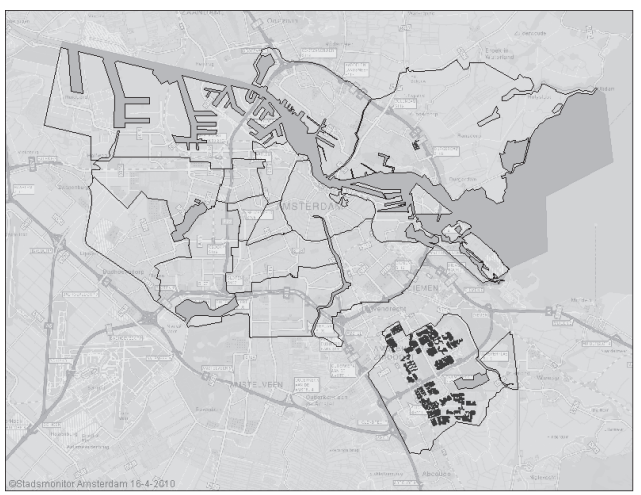

Surinamese

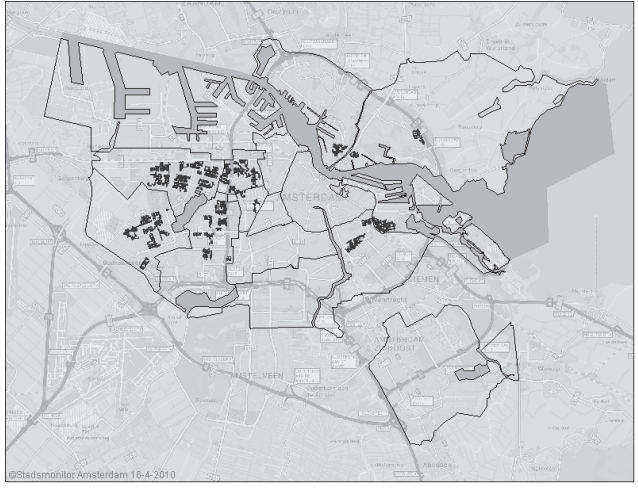

Moroccan

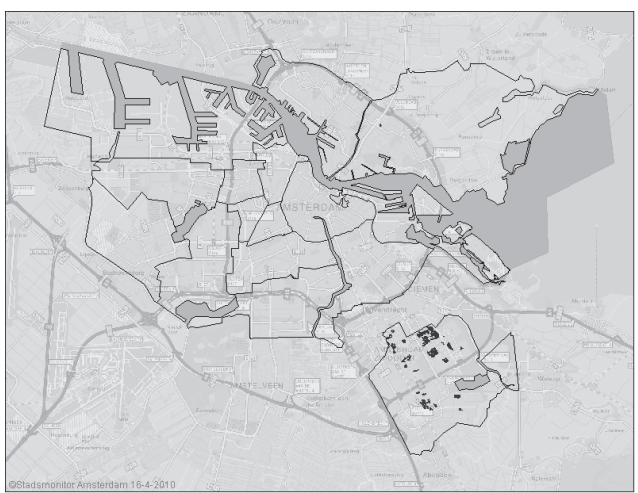

Antillean

Figure 3. Concentrations of four population categories in Amsterdam, 2009. 
From Figure 4 we see that the share of each of the four categories under investigation relative to the total population in the concentrations they live in is fairly stable, except for those of Moroccans. Over the past decade their average share in Moroccan concentration areas rose with 16\% from approximately 30 per cent to approximately 35 per cent; however, we should bear in mind that the share of Moroccans in the entire city raised with 20\%. For the Turkish population these figures were $8 \%$ and $13 \%$ respectively. This implies that relative to the population dynamics regarding these population categories in the city as a whole, there is on average no tendency for increasing concentration. In fact, relatively more Moroccans and Turks were going to live in areas that were not labelled Moroccan or Turkish concentrations.

Table 1. Concentrations of ethnic categories in Amsterdam 2009

\begin{tabular}{lcccccc}
\hline \multicolumn{1}{c}{1} & 2 & 3 & 4 & 5 & $6=(4 / 5)^{*} 100$ & $7=(4 / 2)^{*} 100$ \\
\hline $\begin{array}{l}\text { Ethic } \\
\text { category }\end{array}$ & $\begin{array}{c}\text { Category's } \\
\text { city } \\
\text { population }\end{array}$ & $\begin{array}{c}\text { Percentage } \\
\text { of category } \\
\text { in city }\end{array}$ & $\begin{array}{c}\text { Category's } \\
\text { concentration } \\
\text { population }\end{array}$ & $\begin{array}{c}\text { Total } \\
\text { concentration } \\
\text { population }\end{array}$ & $\begin{array}{c}\text { Percentage } \\
\text { of category in } \\
\text { concentrations }\end{array}$ & $\begin{array}{c}\text { Category's } \\
\text { percentage of } \\
\text { concentration } \\
\text { population }\end{array}$ \\
\hline Turkish & 39654 & 5.2 & 16102 & 68532 & 23,5 & 40.6 \\
Moroccan & 68099 & 9.0 & 32446 & 91235 & 35.6 & 47.6 \\
Surinamese & 68761 & 9.1 & 23511 & 61710 & 38.1 & 34.2 \\
Antillean & 11559 & 1.5 & 2010 & 16895 & 11.9 & 17.4 \\
\hline
\end{tabular}

Source: City Monitor Amsterdam. Geography, University of Amsterdam and O+S Amsterdam.

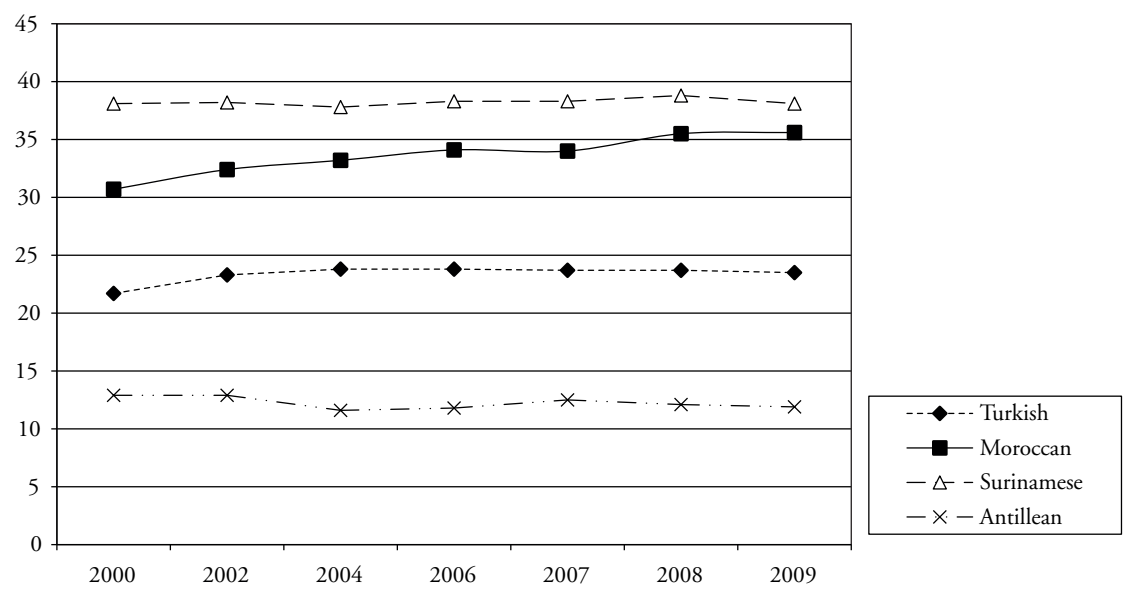

Figure 4. Percentage of each of the population categories in concentrations of these population categories (concentrations include areas where the category involved passes four standard deviations above the mean). 
This is reflected in Figure 5, where the share of a population category that is living in a concentration of that population is presented. If we take the share of Moroccans in 2000 as a start: $43.8 \%$ of all Moroccans lived in a Moroccan concentration, we see that in 2007 this figure had grown with 11 per cent, but then dropped; the growth figure in 2009 relative to 2000 is almost 9 per cent $(47.6 \%)$. However, that growth percentage again has to be seen in the perspective of a 20 per cent growth of the share of Moroccans in the population as a whole.

We therefore can not generally argue that there is increasing separation or isolation of Moroccans. In fact, relatively less (former) immigrants are encapsulated in their own category. The relative spatial integration of Turkish and other immigrant categories, especially Antilleans, is even stronger.

The time frame (2000-2009) is interesting, since after the Al Qaeda attacks of $9 / 11$ and subsequent bombings and social unrest in many places in the world, including Amsterdam, xenophobia and a generally more negative attitude towards immigrants, especially those with an Islamic background, increased significantly. This may have led to stronger encapsulation, especially among Islamic residents, in the Netherlands typically originating from Turkey and Morocco. Such a tendency could not be shown. The share of Turkish inhabitants that lived in Turkish concentrations did not rise, and whereas over the past decade there was an increase of the relative share of Moroccans who are living in Moroccan concentrations that increase was still below the increase of the category in the city as a whole.

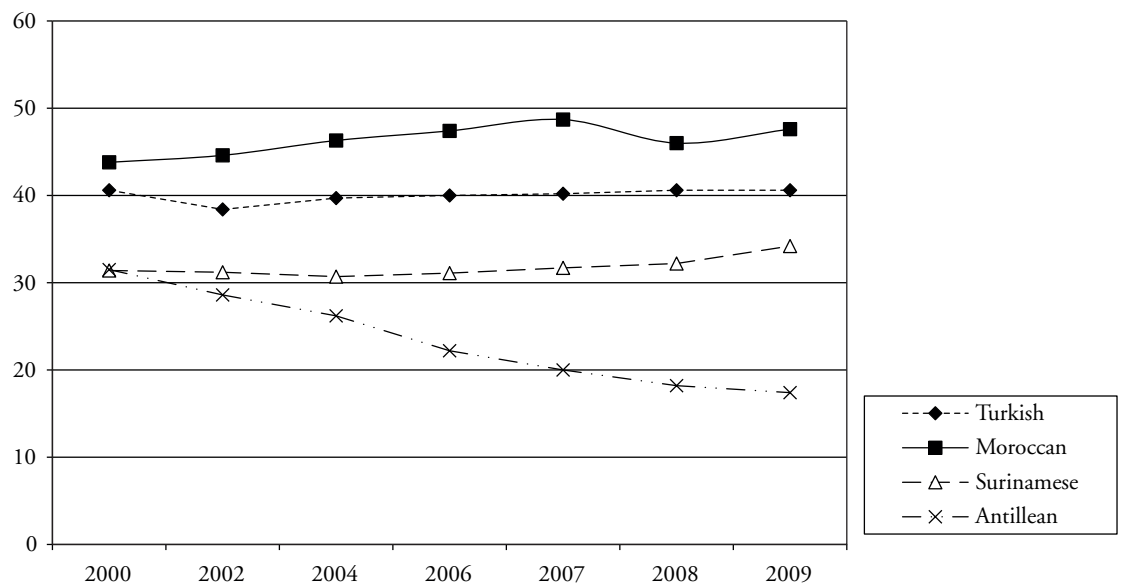

Figure 5. Percentage of each of the population categories that lives in concentrations of these population categories. 


\section{Relations between patterns of concentration and segregation and indicators of (social) integration}

In short, levels of concentration and of segregation of immigrant categories in many European cities in general, and in large Dutch cities in particular, do not appear to be high, nor are they significantly increasing. That, however, does not imply that the concentrations which are developing would not have negative effects upon the individuals who are living in these concentrations. Here I will draw upon two studies, performed with Swedish and with Dutch individual level longitudinal data, to see to what extent spatial concentrations of immigrants have positive or negative effects upon their individual social mobility opportunities, here measured in terms of income development.

\section{Sweden}

The first study is extensively reported in Musterd et al. (2008) and had its focus on the impact of immigrant concentration in small areas in the three largest Swedish cities, Stockholm, Gothenburg and Malmö, on individual migrant's later earned incomes from wages and from entrepreneurial activity. The area unit was defined as a $500 \mathrm{~m}$ x $500 \mathrm{~m}$ grid centred on each individual. The analyses controlled for a wide range of varying and non-varying individual and regional labour-market characteristics (such as demographic and household (change) characteristics, educational attainment, whether experiencing sick leave, parental leave, whether individuals were pre-retired or studying, and others). The data, which were obtained from the Statistics Sweden Louise files, focused on all individuals (entire population) who were between 16-58 years old in 1995 and followed them between 1995 and 2002. The data also allowed us to develop a proxy for unmeasured individual characteristics that permitted us to purge estimated neighbourhood effects of selection bias. Since the relationship between neighbourhood composition and individual's income may be (partially) spurious and explained by unmeasured variables, such as 'level of intelligence' of the individual (which would have resulted in an orientation to a certain neighbourhood and in earning a certain income), efforts were made to control for these unmeasured variables as well. Of course, we could not measure the unmeasured variables directly, but we were able to perform preliminary regression analyses of labour earnings for 1995 which are virtually identical to our main model. We then inserted the residuals (the unmeasured variance) of that model in our main model and regarded that to be the controls for unmeasured variables, such as intelligence.

In the three metropolitan areas 16 per cent of the population was labelled as foreign born. The analyses focused on the largest immigrant categories in the three metropolitan areas, those coming from Bosnia, Chile, Ethiopia, Iran, Iraq, Turkey and Somalia. We modelled average annual income (1999-2002) as a gender-specific and immigrant-group-specific, log-linear function of per- 
sonal characteristics, of characteristics of the neighbourhood(s) in which they reside at the beginning of the period for which we measure income earning (1999) and four years prior, and of labour market conditions in 1999 and 2002. We applied OLS regression techniques.

Immigrant concentration is measured in two ways. First, for each individual we calculated the number of immigrants from the same origin in the individual's grid (excluding the individual him/herself) and then produced the percentage own group and also the density of own group per $\mathrm{km}^{2}$. Second, for each individual we calculated the share of not Swedish born people, and again their density. We applied these latter variables after controlling for own group immigrants to see to what extent other migrants affect individual's income positions.

We also included the share of people receiving unemployment benefits in the areal unit as well as the interaction between that variable and percentage own group and percentage immigrants overall. This was done because one might expect that a weaker socio-economic environment reduces opportunities. Since we also would expect that the efficacy of own group and other group immigrants' networks would be eroded when the socio-economic environment is weaker.

\section{Results}

Swedish immigrants did not typically live in places where their own group constituted a large share of the area unit they belong to. In 1995 for all seven immigrants categories combined, the mean percentage own-group was 5 per cent, for both genders. Nevertheless, there were more than 5000 individual neighbourhoods with more than 500 residents and where at least $15 \%$ is of the individual's own ethnic group. However, immigrants from all groups did typically reside surrounded by large numbers of immigrants. In 1995 on average 39\% of an immigrant's neighbours were immigrants (for males; for females this was 40\%). Overall, immigrants in Sweden do not typically live in neighbourhoods with predominantly own group migrants, but they did live among substantial numbers of immigrants in general.

With regard to the effects of the presence of own group and/or immigrants, for females (all seven immigrant groups combined) we found significant positive effects of 1995 own group immigrant concentrations and significant negative effects of 1999 own group concentrations $(\mathrm{p}<0.05)$. For males these effects were not significant, but for them there were significant positive effects of own group density in 1995 and significant negative effects of own group density in 1999. For females the signs of these relations were as for males, but only the relation with own group density in 1999 was significant.

These findings suggest initial positive effects from co-location with own group immigrants, but negative persistence effects. Initial settlement in an ethnic enclave where others from the same origin are residing may have benefits for learning to know your way in the new society. Help can easily be provided about where to go, learning attitudes and behaviours, get in contact with insti- 
tutions and potential employers, etc. However, the implicit negative aspects of ethnic concentrations start to dominate after a longer stay in these enclaves. We calculated that this was approximately after two years of residence. These findings are consistent with empirical studies by Clark and Drinkwater, 2002 and Galster et al., 1999.

The presence of immigrants in other groups has a negative effect, unless almost everyone in the neighbourhood is employed.

\section{The Netherlands}

The second study is based on analysis of similarly large-scale individual longitudinal data registered in the Netherlands (Musterd et al. fc). The focus of this study was on the impact of various neighbourhood compositions on economic prospects of different categories of residents. We only included those individuals who were staying in the neighbourhood throughout the period of research, 1999-2005. The neighbourhood unit applied was a statistical unit with an average population of approximately 1500 inhabitants. We only analysed neighbourhoods with at least one hundred residents. More than nine thousand neighbourhoods were included in the analysis. The data were obtained from the longitudinal Social Statistical Database of Statistics Netherlands. That database is a merger of three registers: on population data, on incomes, tax and social security, and on housing tenure. In this study we focused on all individuals (again the entire population, not a sample) who were between 18 and 49 years old in 1999; they were followed between 1999 and 2005. Since age is expected to be non-linearly related to income we split the age category. Younger adults are more likely to experience a transition to a first job than older adults. We also separated those with a substantial income (more than 500) and those with a nonsubstantial income and combined this with the age split. Here I will only present some findings for the 25-49 adults who earn at least 500 Euro in 1999 (2.8 million cases). Multi-level linear regression models were constructed. Economic prospects was measured though the (natural logarithm of) income development. Neighbourhoods across the country were incorporated. A range of individual variables was controlled for (such as sex, country of origin, position in household, socio-economic position, housing situation and age). We also used income in 1999 as a control variable and regarded that to be a (partial) proxy for unmeasured individual variables as well. The selection effect was also reduced by focusing on non-movers only. We did not investigate the change of the neighbourhoods over time, and it should be stressed that we still have to face a selection effect because many social climbers will have left the neighbourhood. Therefore, findings should be interpreted with caution.

We measured the presence of immigrants and the level of immigrant mix of the neighbourhoods through using a categorised variable for the shares of non-Western immigrants. If it would all be about the share of immigrants, 
one would expect a monotonous relation between this variable and income development. But when it is the 'ethnic' cultural mix that matters, the relation will be non-linear and could even be U-shaped. For the country of origin we used the most common categorisation in the Netherlands. Someone is labelled Dutch if both parents are born in the Netherlands. If one parent is born elsewhere, the person will be labelled that country. If both parents are born abroad, the person is labelled the country of the mother. On that basis the category non-Western and other categories were constructed.

\section{Results}

As in Sweden, also in the Netherlands immigrants do not typically live in places where immigrants dominate the population. In January 2006, 10.5 per cent of the population was of non-Western origin (11.2\% in 2010), but there were only about 50 neighbourhoods where over 50 percent of the inhabitants have a non-Western background. In almost 700 neighbourhoods the share of non-Western immigrants was at least 15 per cent.

From the analysis we learn that a non-native background is disadvantageous for economic prospects, but that major differences can be found between those who came from former colonies and those who originate from Turkey and Morocco (who mainly arrived as guest worker or follow up migration related to that).

With regard to the impact of neighbourhood composition in terms of the share of people with a non-Western origin the general picture is that a high share is associated with more favourable economic prospects than a low share. Remember that this is after controlling for income differences in 1999 and after controlling for the other variables.

This finding that a higher share of non-Western immigrants has a significant and positive impact on the income development of people living in these neighbourhoods corresponds with the findings presented in the first example, which underline the potentially favourable effect of concentrating people from the same background who could help each other find their way in their new environment. However, two comments have to be made. First, this theory holds for concentrations of one's 'own-group'. A concentration of non-Western residents is rather heterogeneous and it is questionable that a large immigrant mix with different origins, cultures, languages, etc. is very helpful. Second, the effects we measure apply to all residents, so we cannot be sure of the effects on specific population categories only. This pushed us to repeat the multilevel analysis for the non-Western population only. This resulted in different outcomes. Income gain was larger in neighbourhoods with only a limited share of non-Westerners (0-5\%). These results may conceal the potentially positive albeit only initial effects from own group enclaves. The findings may also indicate that a range of neighbourhoods with a relatively high number of non-Western immigrants could face upgrading and gentrification processes, which may especially benefit non-immigrants and/or people with a Western background, and not the migrants. 


\section{Conclusions and implications for policies}

In conclusion, the description of the dynamics of segregation and concentration showed us that although there is some segregation and concentration going on, these processes should not be considered as indications of the development of dual urban societies. Detailed analyses of the spatial distribution of groups of immigrants have shown that even during the first decade of the new Millennium, a decrease of levels of segregation was more common than an increase. The years 2000-2010 were highly affected by the Al Qaeda attacks of 9/11 2001 and by subsequent bombings, social unrest in many places in the world, and wars. This has contributed to anger, but also to xenophobic reactions and a generally more negative attitude towards immigrants, especially those with an Islamic background. One might have expected that these developments would have led to stronger encapsulation, especially among Islamic residents. However, such a tendency could not be shown. In the analyses of Amsterdam data it could be shown that the share of Turkish inhabitants that lived in Turkish concentrations did not rise, and whereas over the past decade there was an increase of the relative share of Moroccans who are living in Moroccan concentrations that increase was still below the increase of the category in the city as a whole.

With regard to the potential effects of immigrant concentrations it was shown that concentrations, more precisely those of own group immigrants, may have temporary positive effects in initial stages of settlement in the country of destination. Positive effects may also statistically pop up, because some of the 'immigrant concentration areas' are typically neighbourhoods with gentrification potential, which show upgrading. However, we could show that this association seems to favour non-immigrants and Western immigrants in particular, not immigrants from less affluent countries of origin. More generally, it seems that concentrations of non-Western immigrants have - albeit small- negative effects upon individual's opportunities.

The findings presented in this paper suggest that it makes sense to continue developing ideas and policies that contribute to avoiding large and persistent immigrant concentrations from developing. Although there is no reason for nervous reaction when an enclave of own-group migrants establishes itself, there is reason to believe that persistent concentrations of own group migrants, and concentrations of larger categories of migrants in general have negative impacts on economic prospects. This is not to say that dispersal policies, or general mix policies should be developed instantly to hinder further development of these concentrations. First because existing concentrations are already highly dynamic and not systematically enlarging, as has been shown in this paper. Secondly, some of these policies may be discriminatory, especially when they get the character of enforced dispersal of specific population groups. Thirdly, one should not take the risk of adding to the stigmatization of immigrant concentrations. Moreover, the 'pathologization' of specific groups should be avoided as well. Policies that specifically target concentrations of 
a delineated population group may be more harming than healing, because that may suggest that the population category is the cause of the problems that are defined. Fourthly, one should first be aware of the causes of segregation. Segregation processes must be seen as 'strong' processes. Forced housing mix programmes aimed at 'break segregation' (Andersson 2006) are difficult to effectuate in meritocratic societies and may even be counter-productive when stronger households move away when confronted with mix they did not ask for. Without a solid understanding of the segregation processes proper, it will be extremely difficult to change the spatial distributions. Fifthly, it makes sense to investigate closer and in more detail the effects of segregation. The elaborate study of large-scale longitudinal data in which neighbourhood effects are addressed actually has just begun. More qualitative and quantitative studies are required that aim at better understanding these effects, the shape of their relations (linear, non-linear), the impact of duration and timing of exposure to certain environments and the relevance of thresholds.

The dynamics encountered so far, however, seem to show that quite some (spatial) integration of immigrants is actually already going on. Research shows positive trends in terms of educational levels and labour market participation of younger generations of immigrants, and language arrears of young immigrants tend to be reduced as well. Young immigrants, higher educated immigrants and second-generation immigrants also have more contacts with others than older, less educated and first-generation immigrants (Musterd and Ostendorf 2009). When their socio-economic position gets stronger, they tend to behave like others in mainstream society. They opt for a larger house, for a better location, for owner occupied living and for higher quality space. Their spatial behaviour does not generally reflect efforts to strengthen own ethnic identities in ever-stronger ethnic enclaves.

Alternative interventions may also be considered. Stigmatization, one of the potential causes of negative neighbourhood effects, may also be conquered through direct interventions in stigmatized areas, for example; integration levels in society, both in the spheres of the labour market and education, but also in social and cultural domains, may also be stimulated by extra attention to access to these domains directly. And individual targeting, as opposed to area-based interventions may also be more effective, and democratic. Perhaps a focus of the attention only on those who apparently belong to the 'trapped', who may not be able to escape from the encapsulated situation on one's own steam, would result in more effective interventions.

\section{References}

Alexander, M. (2003). Host-Stranger Relations in Rome, Tel Aviv, Paris and Amsterdam; a comparison of local policies toward labour migrants. PhD Thesis. Amsterdam: Universiteit van Amsterdam.

Amersfoort, H. Van (1992). «Ethnic Residential Patterns in a Welfare State: Lessons from Amsterdam, 1970-1990». New Community, 18 (3), 349-456. 
Andersson, R. (2006). “'Breaking Segregation’-Rhetorical Construct or Effective Policy? The Case of the Metropolitan Development Initiative in Sweden». Urban Studies, 43 (4), 787-799.

Arbaci, S. (2007). The residential insertion of immigrants in Europe: Patterns and mechanisms in southern European cities. Ph.D. Thesis. London: The Bartlett School of Planning-University College London.

Arbaci, S. and Malheiros, J. (2010). «De-Segregation, Peripheralisation and the Social Exclusion of Immigrants: Southern European Cities in the 1990s». Journal of Ethnic and Migration Studies, 36 (2), 227-255.

Boal, F.W. (1976). «Ethnic Residential Segregation». Herbert, D.T. and Johnston, R.J. (eds.) Social Areas in Cities, 1. Spatial Processes and Form, London, New York: John Wiley \& Sons, 41-79.

Bolt, G. (2009). «Combating residential segregation of ethnic minorities in European cities». Journal of Housing and the Built Environment, 24 (4), 397-405.

Bolt, G.; Sule Özüekren, A. and Phillips, D. (2010). «Linking Integration and Residential Segregation». Journal of Ethnic and Migration Studies, 36 (2), 169-186.

Borjas, G. (1995). «Ethnicity, Neighborhoods, and Human Capital Externalities». American Economic Review, 85, 365-390.

- (1998). "To Ghetto or not to Ghetto: Ethnicity and Residential Segregation». Journal of Urban Economics, 44, 228-253.

Burgers, J. and Musterd, S. (2002). «Understanding Urban Inequality; A model based on existing theories and an empirical illustration». International Journal of Urban and Regional Research, 26 (2), 403-413.

Castles, S. and Millar, M. (1993). The Age of Migration: International Population Movements in the Modern World. New York: Guilford Press.

Clark, K. and Drinkwater, S. (2002). «Enclaves, Neighborhood Effects and Employment Outcomes: Ethnic Minorities in England and Wales». Journal of Population Economics, 15, 5-29.

Deurloo, M.C. and De Vos, S. (2008). «Measuring Segregation at the Micro Level: an Application of the M Measure to Multi-Ethnic Residential Neighbourhoods in Amsterdam». Tijdschrift voor Economische en Sociale Geografie, 99 (3), 329-347.

Domburg-De Rooij, T. and Musterd, S. (2002). "Ethnic segregation and the welfare state». Schnell, I. and Ostendorf, W. (Eds.). Studies in segregation and desegregation. Aldershot: Ashgate, 107-131.

Duncan, O.D. and Duncan, B. (1955). «A Methodological Analysis of Segregation Indexes». American Sociological Review, 20, 210-217.

Elias, N. and Scotson, J. (1994). The Established and the Outsiders, a Sociological Inquiry into Community Problems. London: Sage.

Galster, G.; Metzger, K. and Waite, R. (1999). «Neighborhood Opportunity Structures and Immigrants' Socioeconomic Advancement». Journal of Housing Research, 10, 95-127.

Hall, P. (1998). Cities in Civilization. New York: Pantheon.

Johnston, R. J.; Poulsen, M.F. and Forrest, J. (2008). «Back to basics: a response to Watts». Environment and Planning A, 40, 2037-2041.

Kloosterman, R. and Rath, J. (2003). Immigrant Entrepeneurs; venturing abroad in the age of globalization. Oxford, New York: Berg.

Malheiros, J. (2002a). «Ethni-cities: Residential patterns in the northern European and Mediterranean metropolises-Implications for policy design». International Journal of Population Geography, 8, 107-134. 
- (2002b). "Immigration and city change: the Lisbon metropolis at the turn of the twentieth century». Journal of Ethnic and Migration Studies, 30 (6), 1065-1086.

Martori, J.C.; Hoberg, K. and Suriñach, J. (2005). "Segregation measures and spatial autocorrelation. Location patterns of immigrant minorities in the Barcelona region». Paper presented at the 45th Congress of the European Regional Science Association August 23-27, 2005, Amsterdam, The Netherlands (http://www-sre. wu-wien.ac.at/ersa/ersaconfs/ersa05/papers/225.pdf viewed at 10-02-09).

Massey, D. and Denton, N. (1987). "Trends in Residential Segregation of Blacks, Hispanics, and Asians». American Sociological Review, 52, 802-825.

- (1993). American Apartheid: Segregation and the Making of the Underclass. Cambridge, MA: Harvard University Press.

Musterd, S. (2005). "Social and Ethnic Segregation In Europe; Levels, Causes and Effects». Journal of Urban Affairs, 27 (3), 331-348.

- (fc). «Ethnic Residential Segregation; Reflections on Concepts, Levels and Effects». Clapham, D.; Clark, W.A.V. and Gibb, K. (eds.). Handbook of Housing. London, New York: Sage.

Musterd, S.; Andersson, R.; Galster, G. and Kauppinen, T. (2008). «Are Immigrants' Earnings Influenced by the Characteristics of their Neighbours?». Environment and Planning A, 40, 785-805

Musterd, S. and Ostendorf, W. (eds.) (1998). Urban Segregation and the Welfare State: Inequality and Exclusion in Western Cities. London: Routledge.

- (2009). «Spatial Segregation and Integration in the Netherlands». Journal of Ethnic and Migration Studies, 35 (9), 1515-1532.

Musterd, S. and De Vos, S. (2007). «Residential dynamics in ethnic concentrations». Housing Studies, 22 (3), 333-353.

Musterd, S.; De Vos, S.; Das, M. and Latten, J. (fc). Neighbourhood Composition and Economic Prospects, a longitudinal study in the Netherlands.

Musterd, S. and Van Kempen, R. (2009). «Segregation and Housing of Minority Ethnic Groups in Western European Cities». Tijdschrift voor Economische en Sociale Geografie, 100 (3), 559-566.

PEACH, C. (1996). «Does Brittain have ghettos?». Transactions of the Institute of British Geographers, 21, 216-235.

- (1997). «Pluralist and Assimilationist Models of Ethnic Settlement in London 1991». Tijdschrift voor Sociale en Economische Geografie, 88 (2), 120-134.

- (1999). "London and New York: Contrasts in British and American Models of Segregation. With a Comment by Nathan Glazer». International Journal of Population Geography, 5 (5), 319-351.

- (2009). «Slippery Segregation: Discovering or Manufacturing Ghettos?». Journal of Ethnic and Migration Studies, 35 (9), 1381-1395.

Рніцротт, T.L. (1978). The slum and the ghetto: neighborhood deterioration and middle class reform, Chicago, 1880-1930. New York: Oxford University Press.

Portes A. (1995). The Economic Sociology of Immigration: Essays on Networks, Ethnicity, and Entrepreneurship. New York: Russell Sage Foundation.

Portes, A. and Zhou, M. (1992). "Gaining the Upper Hand: Economic Mobility Among Immigrant and Domestic Minorities». Ethnic and Racial Studies, 15, 491-522.

SAINSBURY, D. (2006). «Immigrants' social rights in comparative perspective: welfare regimes, forms in immigration and immigration policy regimes». Journal of European Social Policy, 16 (3), 229-244. 
Sanders, J. and Nee, V. (1996). «Immigrant Self-Employment: The Family as Social Capital and the Value of Human Capital. American Sociological Review, 61, 231-249.

Sassen, S. (1991). The Global City: New York, London, Tokyo. Princeton, NJ: Princeton University Press.

Van der Klaauw B. and Van Ours, J.C. (2003). «From Welfare to Work: Does Neighborhood Matter?». Journal of Public Economics, 87, 957-985.

WaCQUANT, L. (1993). «Urban Outcasts: Stigma and Division in the Black American Ghetto and the French Periphery». International Journal of Urban and Regional Research, 17, 366-383.

Waldinger, R. (1997). «Black/Immigrant Competition Re-assessed: New Evidence from Los Angeles». Sociological Perspectives, 40, 365-386.

Wilson, W.J. (1987). The Truly Disadvantaged. Chicago: University of Chicago Press. 